DOI: https://doi.org/10.47405/mjssh.v6i6.842

\begin{tabular}{|c|c|}
\hline 4 & Malaysian Journal of Social Sciences and Humanities (MJSSH) \\
\hline $\begin{array}{l}\text { Malaysian Journa of } \\
\text { Social cciences and }\end{array}$ & Volume 6, Issue 6, June 2021 \\
\hline (MJ-sSH) & e-ISSN : 2504-8562 \\
\hline & $\begin{array}{l}\text { Journal home page: } \\
\text { www.msocialsciences.com }\end{array}$ \\
\hline
\end{tabular}

\title{
Study On Shamanism in Primitive Community Trust
}

\author{
Darmaiza $^{1}$ \\ 1Universitas Islam Negeri Imam Bonjol Padang, Indonesia \\ Correspondence: Darmaiza (darmaiza@uinib.ac.id)
}

\begin{abstract}
Shamanism is an idea which is improving in the primitive society, in which is having more in any animistic activity, to relate any living activity which is called "Shaman" is connect believe the spirit life which the human living now. The appearance of "Shaman" in the now living becomes an introducer for people to, tell any difficult inner livings, in the privates or society ones the most in portent for a Shaman which has ability to pray to god with any kinds of aims so that it appears any talks between the deal human with the living ones.
\end{abstract}

Keywords: Shamanism, Primitive Community and Trust

\section{Introduction}

Shamanism is related to beliefs in ancient religions. Therefore, in the study of Comparative Religion, Shamanism can be seen from the evolutionary theory of the origins of religion. According to this theory, religion is the result of a long process of human development towards the unseen. Included in this process are primitive religions that adhere to beliefs in spirits of spirits that are personalized to certain objects, such as dynamism, animism, totemic, fetishism and shamanism. This belief process is not known in the theory of revelation which sees religion as originating from revelations that come from Allah SWT and then delivered by His Prophets and Messengers.

Shamanism is a school that has a tendency to believe in animism, life after death, and worship of spirits or ancestral spirits (Zakiah Daradjat, 1996:30). That is the religion or belief of primitive peoples who think that humans can relate to gods or ancestral spirits. Belief in spirits is one of the hallmarks of primitive religion. Shamanism's belief in the spirit is personified to an object or person who is considered an intermediary between the spirit world and the human world in general. The intermediary in Shamanism is called a Shaman which means "priest", namely a person who can treat (Zakiah Daradjat, 1996:30).

Within the scope of Comparative Religion Science, Shamanism is part of Animism in the context of belief in spirits or spirits that are used to solve various problems of life in certain communities. This is manifested in every ritual in the life of society. In Shamanism, a pawing or shaman who has supernatural powers, who knows to carry out ceremonies for the benefit of society in life, is considered sacred. In this person is considered the ancestral spirits who can direct their lives. This shaman is ecstatic or forgetful, for example found in the Samoyet tribe and tribes in North Asia. This paper will discuss the meaning, history, and influence of Shamanism in people's lives, as well as the Islamic view of Shamanism. 


\section{Definition and History of Shamanism}

The author puts forward the understanding of Shamanism in etymology and terminology in the perspective of primitive people's beliefs. The word shamanism comes from the Tungsian word " saman ", which means priest or shaman. Shamanism is the original belief of the Ural Altaic peoples of North Asia and Europe. This word is used to describe a type of religious practice inter alia in North America (Religious College Development Project/IAIN, 1981/1982:30).

Priests or so-called Shamans are intermediaries between ancestral spirits and the human world who have certain authority over these spirits. The existence of Shamans or priests in the belief of Shamanism becomes a mediation for humans to convey inner complaints related to personal life and community life. No less important is that a Shaman can master incantations or incantations, so that he can "dialogue" with ancestral spirits.

Meanwhile, according to terminology, Shamanism is an ideology or school that tends to believe in allspirits (animism) or life after death, worshiping spirits or ancestors as intermediaries between the spirit world and humans in general (Zakiah Daradjat, 1996:30). These intermediaries are called Shamans who have certain authority over spirits. Shamans usually wear certain clothes, certain symbols, certain tools, all of which are very complicated. Their function is as priests, masters of spells or incantations, as liaisons for ancestral spirits so that they are able to heal sick people (as shamans). Shamanism is closely related to Animism, as a religious phenomenon, animism appears to be universal, found in all religions, not only primitive people, although the popular use of the term is often associated with primitive religions or society on supernatural beings who questioned (Mariasusai Dhavamony, 1995:67). Relation to

Shaman is a Shaman who always offers sacrifices, predicting what will happen according to the provisions of the ancestral spirits.

Based on the above understanding, the belief in Shamanism is a picture of primitive human belief in the spirits of the ancestors who remain as protectors for them. These spirits can be a place of praise for people who can communicate with these spirits, so an intermediary is needed between spirits and humans. The intermediary in this belief system is called a shaman. So, what is called Shamanism is a belief in primitive people who believe in and interact with the spirits of the ancestors through the intermediary of Shamans (priests). This pattern of religious belief with an intermediary system is called Shamanism.

From the description above, it is clear that the notion of Shamanism is the understanding or belief of primitive people about their relationship with ancestral spirits carried out by priests or Shamans. Shamans who read mantras, so that ancestral spirits can treat or grant the wishes of sick people and so on, because Shamans have supernatural powers that can exceed many people and also bring or offer sacrifices to ancestral spirits when the ancestral spirits are happy, he does not interfere with living people. Sometimes a shaman may also be referred to as a king, charmer, or shaman.

Historically, Shamanism developed in the life of primitive people. Primitive society is always filled with invisible magic, namely spirits or spirits who are happy when they are given offerings so that they do not disturb their children and grandchildren and can even help them. Meanwhile, to be able to relate to these spirits, intermediaries are needed (people people) who really know about the occult, these are the Shamans or shamans.

These shamans can contact ancestral spirits, especially in matters of marriage, death, infectious diseases and others. The position of the shaman in primitive society was very important. Therefore, the shaman's job was concurrently as the chief of the tribe. In practice Shamans or shamans are divided into two groups:

i. whose work is related to life problems, such as a shaman who treats the sick, shamans, religious leaders, and sorcerers or sorcerers. 
ii. whose work is related to the issue of death (religious college development project/IAIN, 1981/1982:32).

In the above explanation it is clear that the shaman or shaman functions and is very decisive in the life of primitive society. Shamans or shamans are required to have certain skills, such as extensive knowledge of the supernatural world, the realm of the spirits, and also to memorize spells or incantations that can be used in various ceremonies.

The function of a shaman or shaman is still developing, although the community has advanced with various developed sciences, but in practice there are still people doing the shaman's procedures. For example for the people of Mentawai, Irian, East Timor, the Kubu people in the Jambi area, the Sakai people in the Riau islands and the Dayak people in Kalimantan.

The gods and spirits are considered to cause natural disasters and accidents such as landslides or earthquakes, volcanic eruptions and so on. If their daily life is related to the spirits of the dead, then people think that the gods and spirits sometimes trouble humans, which has an influence on daily life. Thus the people left the affairs of the gods and spirits to the shamans, who gradually got in touch and behaved in such a way that it seemed that they were contacting their knowledge in secret.

Such was the influence of Shamans or shamans who had power in the lives of primitive people. In fact, the Shaman has a secret power that cannot be used by everyone, except for those who have done penance or meditation to connect with spirits.

The beliefs held by the Shamans are in dynamism, mana, fetishism and magic. They perform ceremonies that are carried out by the community together and that are special. If there is a ceremony that must be carried out by the community, then the people who are entrusted with the task are the tribal chiefs. This is where the basis lies the sacred or noble king's power. Usually the primitive tribal chief is shrouded in many taboos (forbidden), so he is prohibited from doing various actions, but he has great power too. For example, he has power over rain and drought, or luck or misfortune, and so on. Often there is also a king who occupies such a place. The Javanese said in ancient times about the point of connection between forces and because of that he was surrounded by various taboos or taboos.

\section{Influence of Shamans in People's Life}

Talking about influence certainly has something to do with people's lives and lives, whether present or past society . Even though life today is completely modern, in certain circumstances, some people still have strong faith in Shamans or shamans, especially in treating illnesses and sometimes asking questions to please them, they are still used.

"Shamanism thrives in the Southern regions, the gods that are invoked and invoked by them are the mountain gods and the river gods. Shamanism adherents, both men and women, in performing rituals of worship perform ceremonies, then take a bath, wear perfumes and dress in beautiful and beautiful clothes, then sing and dance to the accompaniment of certain music, calling out the gods. to be able to go down together in an erotic atmosphere. Then, an extraordinary state and in a state of some kind of trance or possession of the spirits encompassed them. When they regained consciousness, the gods had abandoned them. They then lamented and wept for the departure (Project for the Development of Religious Colleges / IAIN, 1981: 111). Based uraia and above it is clear that a very large Shamanism influence in Community life, especially if the religious knowledge is lacking, so that everything is connected with a power-power and soft power or human spirits who have died. There are times when a kind of trance or the arrival of spirits that enter into a person to treat the person and sometimes can explain conditions that are supernatural and are very secret.

In the development of major religions including Hinduism, Buddhism, Christianity and others, there is still this Shamanism belief, such as the Chinese community in Indonesia. They are as strong as possible still faithfully defending their ways of living and thinking. With the convergence of religions 
in Indonesia, these religions are still adhered to by some people in Indonesia, especially other influential people in Indonesia. Hindus and Confucians have a very strong relationship with Shamanism or shamans because they will be able to relate to Shamans. spirits to ask for help and even their lives in the world depend on the existence of spirits, namely the existence of the highest power above the sky that determines the lives of people on this earth. So, between the creatures above and below there needs to be a relationship, namely Shaman who exceeds the knowledge of the common people.

Actually there are still many Shamans that can be said to exist in every tribe. Shaman is a kind of religion-magical life. Unlike other people who are controlled by spirits, a shaman must be able to master and control spirits, meaning able to communicate with spirits that have died. He alone is able to see spirits to the point of knowing their forms. Some think of them that it is the spirits of women who become the wives of the shamans so that they can assist the shaman in his experiences.

Animists feel always overwhelmed by invisible forces, namely spirits or spirits and this feeling drives them to always try to please these creatures. They try earnestly so that the spirits do not become hostile to them, they also hope that their livelihood will always get the help and help of spirits, it turns out that there are those who can do it themselves, to contact the ancestral spirits. The intermediary must be someone who knows nature gain. These are Shamans or shamans or balians. Shamans "shaman" or in need of marriage, death, infectious disease or plague and others. Because the position of the Shamans or shamans is very important in primitive society, then it is not uncommon that they are also tribal chiefs.

The explanation above is that the shaman's function is to connect humans with shamans or shamans to grant their prayers. Shamans or shamans are required by skills such as extensive knowledge of the supernatural world, the realm of the spirits, and must also memorize incantations or incantations that can be used in several ceremonies. Especially about sorcerers or sorcerers, especially sorcerers, especially black magic, we must realize that primitive Animism people think that goods or objects mean a lot to their owners. These Shamans or shamans can provide help to the community, for the safety of their lives. Lost items or objects belonging to someone can be used as black magical magic items so that they can bring illness, disability for life or even bring death.

Indeed, magical actions are the same as the magic actions of people who are experts in using the supernatural powers or powers found in this universe, or otherwise breaking the powers of something in an irrational way that creates a terrible or frightening feeling. That is what is called a magical act. Knowing how to use power or powers or defeating them, that is what is called magic or witchcraft. Koentjaraningrat means magical, namely occult sciences and he took Frazer's definition of magic, namely all human actions to achieve a purpose through forces in the supernatural world.

Magical acts are often performed in various regions in Indonesia, Dabus is one form of action. In the dabus show, it can be seen how a magician or dabus expert comfortably carries or drapes an iron chain that is red hot after being burned to his neck, or inserts a sharp and long dagger or other sharp weapons into the body (Zakiah Daradjat: 1996: 120).

For example, there is a disease called living in the area of West Sumatra. This disease is said to be a disease caused by witchcraft. This pain is usually suffered by a person on his neck or chest, at first it is shaped like a boil, over time it breaks, becomes infected and becomes continuous, develops, fester, usually the patient cannot recover until his death. But if there is a shaman who has more magical powers and the strength of the the perpetrator or the magician, the shaman can succeed in helping him (Zakiah daradjat: 1996: 120).

Help can be done by treating directly with magical powers as well, or by turning the direction of the magical action back to the perpetrator, so that the disease goes away from the first sufferer, then attacks the person who caused it. 
Here actions and magical powers fight with each other and if one of the magical powers of a person is only mediocre, then it is very likely that he himself will become a victim of his half-hearted actions or knowledge.

The disease is said to be made in various ways. There are those who stick a needle into a banana heart, as a result, the target person will suffer pain in the chest or the chest that is left behind. There is also a way of pricking orange thorns or orange tree thorns, it can also be a rusty nail into the top of the banana stem. It is hoped that this will grow the disease on the neck of the person being addressed and so on. Healing by a shaman is usually done by finding where an object containing magical powers is inserted, if it encounters it, then the object is called and the disease will be cured.

Magical actions performed are usually preceded or dilator-backed by feelings of hurt-except magical acts in the form of spectacle-because they are insulted, disappointed, cheated and so on or just want to practice their knowledge, so, try it. And this deed can be done alone, if indeed magicians or sorcerers, but can also or mostly done by a handyman the magic that was actually the process was at someone's request.

As a result of this action, the results are varied. It can take the form of a physical illness as mentioned above, it can also take the form of a severe mental disorder, such as insanity, or moderate, such as forgetfulness of memory or mild as what is known as infatuation. These disturbances can be referred to as distractions because they are made or done by people.

The tools used for this magical practice besides needles, thorns, nails, there are also socalled sembilu, namely plates or very sharp outer slices of bamboo skin. In addition, the incantation or incantation is no less important. Other tools are still like arrows, sound tools, water, mirrors or other glass and so on.

In a youth relationship, a man who is disappointed or hurt by a girl he admires, often also speaks magic. With the skills of the young man or by asking for help from a sorcerer, the girl can be driven crazy and run around the night looking for the girl. the young man he had hurt. Usually, this girl is harassed with magic through the sound of a flute if the young man only intends to conquer his heart, not wanting to cause harm. The bamboo flute was blown late at night, the sound was so low that it reached the girl's ears, causing the girl to try to find out where the melodious flute came from, so that her heart felt like it was being torn apart. Or it could be that the girl is encouraged by the sweet sound of the buzzing of the baking pans that are released at night.

These voices or sounds are all filled with incantations or incantations so as to give rise to certain impressions for the person being targeted as a target. For example, the sea people or known as the extribe around the Riau archipelago who live in groups on boats, are known for having strong magic. If from time to time they are accompanied by men and women, as well as girls in very flashy colorful clothes, going ashore into the city, shopping to buy what they need, do not try to belittle, insult or spit near them.

From the above explanation that this magical practice is the treatment of Shamans or shamans in daily life to provide help by means of the incantations or incantations used. This activity is for the practice of black magic for damaging people or abusing the body or body.

Based on the above incident in order to prevent him from doing something harmful, he was shown a medicine pipe, a sick pipe, which is used in ceremonies. Because of the magical power of the object, he seemed to be paralyzed. But he was released again, attacked the women, hit the dancers who became buffalo. By this action the hunting of buffalo is guaranteed and by it the general welfare is guaranteed, because of the magical deeds of the Shamans.

Batin, the leader of the Sakai tribal community in the Mandau area, Riau, is both a shaman and a shaman. If he would carry out the task of healing, especially throughout the village must hold a ceremonial dances at night called badikie. This dance is accompanied by a crowd, held above the 
house, accompanied by singing and drums, running for hours, jumping around and around until the mind and some of its petrs lose consciousness and enter the metaphysical realm. It was at that time that he did his medical work with some of his assistants. The treatment is carried out by rubbing the hands, popping the sticks that were originally brought along in the dance, continuing to caress the cloth on the sick person's body from the head to the toes who are lying down. That is the implementation of the duties as a shaman, besides that, the next day, where the shamanic treatment has been carried out, the treatment is complemented by shamanism, namely the mind is fresh and conscious, giving certain herbs as medicine to be drunk or eaten or ordered to the sick, also herbs for bathing.

This shamanic practice can also be done while sleeping. Once upon a time, in Pagar Alam, South Sumatra, a mother who was known as a dukun who helped many people, from various spiritual or physical complaints. One night around 1966, the son of a shaman mother who was studying in Yogyakarta returned to her village. Because the situation was still very warm because of the G.30.SPKI rebellion, the son apparently asked his mother to give him protective equipment that was stronger and more powerful than what he had so far. The request was apparently passed on by the mother to her deceased parents by calling for her spirit. The deceased during his lifetime was a famous and respected person, died also by the community, because of his expertise, wisdom and knowledge (Zakiah daradjat: 1996: 139).

The practice as above is still carried out by modern people until now in the regions, due to the lack of knowledge of the Islamic religion, so that primitive practices are still carried out, because they ask through intermediaries to ask Allah SWT. For example, they call out how to call it is not known, it may be carried out before bedtime, what is clear is, the call is accepted and fulfilled. At around 03.30 in the morning, the spirit of the deceased came or went home. At that moment a man's voice spoke clearly at the front of the outer entrance. The greeting was answered by the mother who was lying asleep, there was a direct question and answer between the mother and her late father which started with "what's wrong with you calling" and answered by the mother, this... came home from java wanted to ask for something else.

The next one who came asked "where is he", answered "it was answered that he was sleeping there", called, he jumped up as if surprised from his sleep and continued to kneel at his mother's head. From that moment on, there was a direct question and answer session between the child and his late grandfather through his mother.

The conversation and question and answer was so clear, no different from the conversation of two people face to face, interspersed by a third person, namely the mother. Only the mother makes two kinds of voices, namely a male voice, if it is her father who speaks and a female voice, if it is she herself who speaks. The conversation that lasted for half an hour ended with a warning given by the newcomer to his grandson who wanted him to be given a new fence. This wish was not allowed by the newcomer by saying, "no need, why ask for a new one, it already exists, use it." just the existing one, no need for a new one, that's enough, don't want the new one!" Finishing saying that, the visitor asked to say goodbye and returned to his residence. Because he still has a lot of work to do and he is also busy with various meetings with his colleagues (in the supernatural).

Here it is clear that the function of people as intermediaries between the supernatural and the real world is carried out in an unconscious way, namely sleeping. Because during the conversation, the mother remained in a position and a state of sleep, then after the one who came to her said goodbye and left, she moved, stretched, just as if we had just woken up from a deep sleep. As soon as he woke up and saw that his son was still resting near his head, then he asked "why are you here, go back to your bed", after that the child returned to his original place and lay down again, it was already dawn.

James provide a description of shamans and herbalists is yes the integration of the shaman and the shaman within a person. Moreover on shaman belonging priestly functions, prophetic, and position it serves to grant to their prayers so that his prayer terkabu 1 da 1 am his life. 
Then someone in the tribe - Siberia can also be inherited, heritage can be carried out by a father who has become a shaman, to his son, that is by selecting any one of the boys who exhibit traitscharacteristics, there is a will, be quite -silence and so on. If there was, then the child would have to do everything in his own power to keep the memory loss state within himself. Thus, here no one can become a shaman of his own free will.

The shaman ka shallow appears to work as a product of grace that cannot be separated from himself and sometimes as an instrument of the spirits with whom he is associated.

In addition to the examples in Pagar Alam City that have been written above, the shamans of various ethnic groups are indeed intermediaries between the human world and the spirit realm and function to meet human needs in order to be in touch with ancestral spirits.

Shaman can summon that spirit and bring it into itself, and through that spirit shaman works and talk to him and to whom he want so more people believe in making requests or pleading for help for prayer or his request was granted can be received in life

Among the Transbaikali Tungus, a man who wanted to enter a chastity assembly, he first explained that a certain dead shaman had come to him in a dream and asked him to be his bride. After that he showed his body became weak like a person who was dazed and anxious. After that suddenly spoke in a language that was not understood by others, then fell, unconscious, after that he ran into the forest, lived on a tree., continued to throw himself into the fire and the water, holding a gun and injure himself with the weapon and he usually behaves like; madman.

Having had enough of this, an old shaman was then invited to teach him the knowledge of spirits and to introduce them to the various vocations (spirits). This is considered a trial or training period. During training and they appeared to him as people, sometimes as birds, giving him strength and teach him about magic.

In the Maidu tribal environment in California until now, it's just the shaman is very important, and comfortable is a very important person too. In a society that does not have a clear system of government, the shaman occupies the highest position a layer of society, then he is the most honorable and as a ruler, then more obeyed than the leader (Zakiah Daradjat: 1996: 142).

The Yakuts of Siberia believe that every shaman holds an external spirit, they believe, has two kinds of spirits, namely the inner spirit and the outer spirit one of those spirits reincarnated an animal. Beyond that spirit no -one can find it; it is much the hidden in the rock or in distant caves. Only once a year, which is when the last ice melts, can the spirit be contacted by the shaman adal shaman who heals, the guidance of the spirits, he can intersect inner world to find and capture people's spirits that sick and took him to real. To bring back that spirit exists the paths that the shaman may take are: secretly he descends into hell, or dives to the bottom of the deep sea or soars into high.

There are also puppeteers in Java who call it a shamaniah. This is stated by Hazeu,: according to him, the early puppet instructions were a shamanistic ceremony that intended to fulfill the human need for contact with ancestral spirits. Ki Dadang is a ceremonial center that by describing the behavior of the ancestral spirit, will attract the spirit to the place of ceremony and into his body. Thus ki Dalang is similar to shamans in other nations, is a medium for these spirits.

Thus, it is clear that for people who believe in superstition, shamans and shamans are very much needed, appreciated and also worshiped who have a fairly important dual function, namely mediators between humans and the supernatural or spirit and overcoming all kinds of suffering. 


\section{Islamic View of Shamanism}

Shamans have a very strong connection with magic. Magic work is very contrary to Islamic aqidah (believe), because magic work comes from the work of Satan. As a result, humans have supernatural powers and have intelligence about the occult. This is related to satan or shamanism, says Allah SWT:

.... And that there are some men among mankind asking for protection [1523] from some of the men among the jinn, so the jinn add to their sins and faults.[1523] were among the Arabs when they passed through a deserted place, So they sought refuge from the jinn whom they considered powerful in that place.

Based on the information above that a man guides, helps, or cooperates with the jinn and eventually they become arrogant, says Allah SWT: 221. Shall I tell you, to whom the devils descend? 222. They come down to every more sinful liar, 223. They turn their hearing (to Satan), and most of them are liars.

The explanation of the verse above talks about people who use magic, namely people who are associated with Satan. Satan is a liar and likes to be wary of humans and deceives humans so that they fall into the valley of error according to the word of Allah SWT:

Meaning: And thus we have made enemies for every prophet, namely the devils (of the type) humans (of the type) jinn, some of them whispering to others, beautiful words to deceive humans). If you want, they will not do it, and they will remain and what they made up.

From the description of the verse above that the actions of the shaman have a lot to do with demons and jinn. While the devil is the enemy of man. So if humans want to be helped by the devil then this is clearly not in accordance with Islamic teachings, let alone divination and incantations. Satan's actions want to disbelieve in humans. Which is in accordance with the word of Allah SWT: 16. (The persuasion of the hypocrites is) like (persuasion) Shaitan when he said to humans: "You disbelieve", then when the man has disbelieved, then he says: "Indeed I am free from you, because I am afraid of you. to Allah, Lord of the worlds."

The verse above explains, the devil likes to plunge humans into error, and is very hostile to humans. Humans should be careful with Shamanism, because it can destroy the way of thinking and demean human dignity on the side of other creatures.

\section{References}

Adofo, S. (2013). Challenges And Coping Strategies Of Student Nursing Mothers In Tertiary Institutions In The Greater Accra Region Of Ghana (M.Phil). University of Ghana.

Ministry of Religion RI (1980). Al-Quran and translation, Semarang.

Ali Mukti. (1970). Origins and ethics of Religion, Yogyakarta: Nida Foundation.

Anwar Ali (2005). Comparative Religion and Philosophy, Bandung PN. Pustaka Seria.

Dhavamony Mariasusai. (1995). Penomenology of Religion, Yogyakarta, Kanisius.

Daradjat Zakiah. (1996). Comparative Religion, Jakarta Bumi Aksara.

Honig AGJr. (1987). Agma Science, Jakarta: BPK, Gunung Mulia.

Muchtar Adeng Ghazali. (2000). Comparative Religion Science, Bandung, PN. Pustaka Seria.

Religious College/IAIN Development Project. (1981/1982). Comparative Religion, Jakarta.

Religious Higher Education Development Project / Central IAIN (1981). Comparative Religion, Jakarta.

Rahmat HOK. (1979). From Adam to Muhammad A Study on Religions, Malaysia, PN. Second CT Safe Library.

Umar Hasyim (1975). Satan As Accused In Matters of Magic, Superstition, Shamanism and Amulets, Surabaya.PT Bina Ilmu. 